\title{
Disruption in the consumer decision-making? Critical analysis of the consumer's decision making and its possible change by the COVID-19
}

\author{
Ríos Lama Cristian Armando ${ }^{1}$, Vargas-Merino Jorge Alberto ${ }^{2}$ \\ Universidad César Vallejo \\ Email: rlcristian@hotmail.com \\ Universidad Privada del Norte \\ Email: jorge.merino@upn.pe
}

Article History: Received: 11 January 2021; Accepted: 27 February 2021; Published online: 5 April 2021

\begin{abstract}
A multidisciplinary concept of consumer science and a disruptive pandemic. How are these elements intertwined? In this sense the purpose of this article is to know how the purchase decision could be changed by the covid-19. A holistic analysis of both the psychological and economic effects of a pandemic, impacts from the generational theory, and how this could cause security to become more relevant was carried out. It was carried out a systematic review of scientific literature consulting 304 articles, being 106 the selected ones, under high impact criteria. It is presumed that consumers will make slightly more rational decisions, although this will be subject to factors inherent to specific scenarios, so it is necessary to perform multivariate empirical research.

Index Terms: consumer decisions; pandemic; covid-19; disruption; generational cohorts.
\end{abstract}

\section{INTRODUCTION}

In 1910, John Dewey presented the purchase decision process, a concept that even today has vital relevance in various fields of consumer science (Ewerhard et al., 2019). Like him, several authors have presented different models that try to provide an overview of how an individual seeks to acquire a particular good, tangible or intangible.

Certainly, human beings are able to understand and comprehend the behavior of other people (Schaafsma et al., 2015), which makes it possible to translate into a frame of reference the possible guidelines to be followed by consumers. Even so, it is also likely that sometimes the complexity of human beings exceeds any type of scheme that tries to pigeonhole their actions in a certain pattern, since the rationality assumed within many models is not necessarily contemplated in daily life (Frederiks et al., 2015). In addition to this, there are also external agents that change the way in which buyers behave.

All this being said, it is presumed that over time marketing academics have constantly conducted studies to increase the accuracy of their models, while taking into consideration the possible implications of external factors. Suddenly, however, a disruptive agent has appeared that is likely to greatly change the way consumers buy, the covid-19 pandemic. According to research by Rousseau et al. (2013), during a pandemic there is concern and panic among the population, especially when tragic events of a sensitive nature occur, such as the death of a minor or a pregnant woman.

Continuing with the idea of the previous paragraph, panic spreads easily through social media, being even faster than covid-19 itself (Wilson and Chen, 2020), due to the deliberate action of individuals who viralize false information (Depoux et al., 2020). Larson (2018) had previously visualized how pernicious misinformation and emotional contagion can be in the wake of a pandemic. The latter is defined as the tendency to take on the sensory, motor, physiological, and affective states of others (Hatfield et al., cited by Prochazkova \& Kret, 2017), especially negative ones. (Spoor \& Kelly, cited by Kelly et al., 2015). Of course, in the wake of the global economic recession 
because of this virus, economic crises will be triggered that will also change the consumer in a noticeable way (Smeral, 2009).

Given the above, it is presumed that the covid-19 pandemic will significantly change the status quo of a society, specifically how individuals process the purchasing decision, so this paper seeks to provide an initial theoretical contribution by answering the following question How might the purchasing decision of consumers change as a result of the covid-19 pandemic?

The purchase decision is a very little explored concept in crisis situations. This is denoted by observing the lack of empirical research on consumer behavior in economic crises (Kaytaz and Gul, 2014) and the limited literature on the influence of such crises on purchase intentions (Lins Ferreira et al., 2017). It should also be mentioned that the study of behavior in the context of a pandemic is only minimally developed (Flowers et al., 2014), although it is possible to rescue the work of Wen et al. (2005), which shows how an epidemic changes consumer preferences.

For the above reasons, this review seeks to understand how consumer purchasing decisions could change as a result of the covid-19 pandemic. By achieving this objective, we will be able to provide relevant theoretical knowledge that can help and encourage future empirical research on the topic in question in concrete scenarios.

Next, the methodology of the present work will be explained, to then begin to develop the research through four key sub-themes: purchase decision: theoretical evolution of a multidisciplinary concept, the presence of covid-19 as a herald of change, the various generations of consumers and their possible changes as a result of the pandemic, and the return of security as a key purchase factor. Finally, the research will be closed with the conclusions, in addition to the references, where all the authors who have facilitated the development of this review will be mentioned.

\section{METHODOLOGY}

The present research work was a systematic review of qualitative literature; this is defined as research that locates, selects, evaluates, analyzes and synthesizes information from existing studies, seeking to consistently answer the research question. (Thomé et al., 2016).

The scientific articles presented in this document were obtained through the following scientific databases: Google Scholar, EBSCO, ProQuest, ScienceDirect, Elsevier, Semantic Scholar and Research Gate. The main keywords that allowed the collection of the information were the following: "Consumer Decision-Making", "Decisionmaking process", "Decision-making model", "Consumer Behaviour", "Pandemic Behaviour", "Coronavirus", "Covid-19", "Crisis Behaviour", "Panic Buying", "Impulsive buying behavior", "Social isolation", "Generation Cohorts", "Zers", "Xers", "Baby Boomers", "Millennials", "Maslow hierarchy of needs" and "Conspicuous consumption".

In order to carry out this systematic review, 304 scientific articles were consulted, distributed mainly in the following disciplines: medicine, economics, psychology, marketing, sociology and administration. Of all the articles consulted, 99 articles were selected. The inclusion criteria used were as follows: the article had to belong to an indexed and refereed journal, contain relevant and accurate information on the topic in question and preferably be as recent as possible. On the other hand, articles were excluded if they contained redundant information, belonged to journals that were neither refereed nor indexed, or were older than 20 years. With respect to this last criterion, exceptions were made for those papers whose contribution is of vital importance in this research or which are currently relevant.

At the same time, in order to present relevant knowledge, articles were chosen from journals with a good profile according to the Scimago Journal and Country Rank portal. 84\% (83) of the articles presented belong to quartile one, $14 \%$ (14) of the articles cited belong to quartile two, and $2 \%$ (2) of the articles used belong to quartile three. 


\section{RESULTS AND DISCUSSION}

\section{Purchasing decision: theoretical evolution of a multidisciplinary concept}

In economics, there is an approach called rational choice theory, which argues that individuals choose the option that allows them to obtain the greatest benefit (Fawcett et al., 2014). However, Hinterhuber (2015) retorts that consumers are not that rational, since, purchase choices can become defined through irrelevant attributes. These discrepancies regarding how consumers choose what to buy are not unique to the 21 st century.

Social sciences such as psychology and economics have long been at odds with each other, the latter almost uniformly assuming that human behavior is rational, while psychology has always considered irrational and rational aspects within people (Simon, 1986). Although some prominent researchers from both disciplines have criticized many of the principles of economics for being psychologically unrealistic (Rabin, 2002), and in recent years, insights from psychology have been incorporated into economics (Chetty, 2015), it is necessary to emphasize that both positions are strongly supported and this research does not seek to enter into such a debate, but to encourage future projects on that topic.

In short, purchase choice has achieved the unification of psychology and economics, with practical results in social policy and marketing (Foxall, 2003). Thanks to the efforts of both social sciences, the practical concept of the purchase decision has been developed.

Usually, the purchase decision is described as a process composed of the following stages; recognition of a need, information search, evaluation or comparison of alternatives, the purchase decision and post-purchase behavior (Armstrong and Kotler, cited by Rodiger and Hamm, 2015). Such a definition may seem narrow for a universal and influential assumption of consumer behavior literature (Olshavsky and Granbois, cited by Rezaei, 2015), especially when the purchase decision is involved with different disciplines; such as psychology, sociology, consumer behavior, marketing, computer science and even artificial intelligence (Roozmand et al., 2011).

Specifically, The purchase decision is a complex matter that has many influential factors that interact with each other (Lunn, 2015), among which stand out; new technologies (Pantano et al., 2017), the point of sale (Bellini et al., 2017), the place environment (Sunaga et al., 2016), the consumer's planning (Bellini et al., 2017), their internal capabilities and motivations (Payne et al., cited by Karimi et al., 2018), traditional and online word-of-mouth (Huete-Alcocer, 2017), time (Godinho et al., 2016) shopper's own particularities (Viio and Gronroos, 2016) and even emotions (Achar et al., 2016), to name a few.

After what has been expressed, the latent complexity of this term can be observed, which increases when knowing that there are situations in which the planned purchase process is completely or partially surpassed, occurring impulsive purchase decisions. Impulsive buying behavior is correctly defined as a sudden, compelling and hedonically complex purchase decision, highlighting that the speed of the decision process prevents careful consideration of available alternatives (Badgaiyan and Verma, 2015). Although marketers recognize the importance of external factors influencing impulse buying identifying them is indeed difficult, because these are generally inconsistent due to occurring in different types of items (Wu and Lee, 2015).

Another aspect that broadens the purchase decision is the involvement of technology, even more so in this stage of pandemic, specifically the Internet and the consequent e-commerce. Cosenza et al. (2014) had already mentioned that cyberspace was gaining relevance in people's lives and how they shop, so they recommended studying possible changes, one of these would be the need to create a customer experience full of interactions at each stage of the purchase decision process, specifically in a social commerce context (Wang and $\mathrm{Yu}, 2017)$. It is a fact that the online consumer buying behavior does not necessarily possess the same characteristics as the traditional one (Koufaris, cited by Karimi et al., 2015), starting from that premise; it is understandable that there is a need for new knowledge, theories and models of Internet consumer behavior (Pappas, 2016); especially because of the unique factors that e-commerce brings, such as: the availability of large amounts of information resulting in tedious decision making (Hölscher and Strube, cited by Karimi et al., 2018) and electronic word of mouth.

As there are different influential factors in the choice of a buyer, several authors have opted to structure models that allow a general understanding of the consumer's purchase decision; in order to identify, categorize or simplify 
the various agents in each stage proposed; to subsequently devise strategies that contemplate the consumer in each phase.

Voramontri and Klieb (2019) mention that since the late 1960s, different models have been presented with the aim of capturing consumer buying behavior, one of which is the Nicosia model, which divides the decision process into four fields of action: consumer attitude, information search and evaluation, the act of buying and feedback. Another older model is the Howard-Sheth model, which has four sets of variables: stimuli, perceptual constructs, learning constructs and outcomes. Likewise, the EKB model also has four parts: input information, information processing, decision stage and decision process variables. Although these captured the essence of the traditional purchase decision process from different approaches; they were criticized for being too complex, imprecise and lacking empirical support (Karimi, cited by Voramontri and Klieb, 2019).

In recent years, purchase decision models have been able to distance themselves from the traditional model. For example, the consumer decision journey is a non-linear model with four phases: consideration, active evaluation, moment of purchase and post-purchase experience (Court et al., 2009), characterized by perceiving the purchase decision as a constant process in which experience is gained with each purchase, in order to use it on subsequent occasions (Court et al., cited by Batra and Keller, 2016).

\section{Pandemic of covid-19: A harbinger of change?}

Pandemics and epidemics are unfortunate events that threaten health and socioeconomic well-being (Gobat et al., 2017), specifically on human mental health. These complex events are highly relevant in the purchase decision, as their impact can completely impact consumer preferences, as was the case in the Chinese tourism sector after the 2002 severe acute respiratory syndrome (SARS) epidemic (Wen et al., 2005).

After what has been said, it is very difficult to believe that the covid-19 pandemic will not bring with it a series of changes in consumer behavior, since it is capable of generating such negative psychological states as anxiety, fear, stress, depression or various sleep disorders (Torales et al., 2020), which can even affect health professionals (Xiang et al., 2020). Kemp et al. (2014) support this idea by mentioning that the loss of control due to a natural disaster causes fear and anxiety, state of extreme stress and worry in the wake of an immediate or remote threat (Calhoon and Tye, 2015). It is assumed that the presence of these disturbances will influence the emotions of individuals, recalling what was said in the first sub-theme it is theorized that this change in emotions and motivations will cause variations in the purchase decision.

Certainly, anxiety and depression are relatively common disorders around the world (Cryan and Holmes, 2005), the latter standing out for its symptomatic heterogeneity (Snoek et al., 2015). However, it is very likely that current circumstances are enhancing the intensity of such disorders. For example, social distancing is a disposition that seeks to reduce personal interactions in a community in order to avoid contagion from unidentified infected individuals (Wilder-Smith and Freedman, 2020). Although this is done for a reasonable reason, it is fully known that social isolation acts to the detriment of health (House, 2001; Holt-Lunstad et al., 2015), being considered worse than smoking 15 cigarettes a day (Tate, cited by Cohen and Tavares, 2020). Likewise, it leads to problems related to physical, emotional and sexual domestic violence, as evidenced by the $25 \%$ increase in calls to organizations against domestic violence in the United Kingdom (Nicola et al., 2020).

Adding to the distancing, Erku et al. (2020) mention that we are also currently facing an "infodemia", a term that explains an excessive amount of dubious information that confuses the general public. As a consequence of this, it can be stated that there is misinformation capable of causing confusion and irrational behaviors (Mian and Khan, 2020) that even hinder the actions of health professionals (Smith et al., 2020). This concept is directly linked to consumer behavior by highlighting the following: misinformation and the spread of rumors related to the supply of staple products can cause panic buying (Frank and Schvaneveldt, 2016).

Panic buying is a relatively unexplored area of consumer behavior (Yuen et al., 2020), proof of which is that there is still no scientific consensus regarding its definition (Arafat et al., 2020), although it could be interpreted as the action of buying large quantities of products that an individual considers essential because of a possible threat. Its main triggers are presumed to be the inability of humans to estimate the duration of a crisis situation (Sterman and Dogan, 2015) and the need to protect loved ones or oneself (Sim et al., 2020). 
Definitely, panic buying is an aspect of the purchase decision that should be studied in greater depth, because it can be linked to solid marketing concepts, such as: risk in consumer behavior, which explains the uncertainty behind each purchase (Taylor, 1974) and perceived risk, which explains how consumers seek to avoid a bad purchase in detail (Mitchell, 1999). It is emphasized that, shopping can alleviate the stress caused by a disaster (Sneath et al., 2008) However, defining why some affected people opt for austerity and others choose to spend on hedonic products or services (Kemp et al., 2014) could contribute to the theory of shopping behavior after a disaster or specifically, a pandemic.

With all of the above, the presence of the covid-19 pandemic in the psychological aspect of consumers' purchasing decisions is clear. However, its influence is not limited to this aspect alone, but also extends to the economic sphere.

In short, the pandemic of the new coronavirus has created worldwide economic chaos in a way not seen since at least the Great Depression (Laing, 2020), in a short time, it has already been possible to observe a notorious decline in the market price in countries such as China or Japan (Shigemura et al., 2020) and falls of $45 \%$ in the price of shares of transnational companies in the mining sector (Laing, 2020). It is therefore necessary to estimate the economic impact of this phenomenon, as was done with the SARS epidemic or the September 11 attack (Smeral, 2009).

Unfortunately, the literature on consumer behavior in economic crises is limited and does not contain abundant empirical knowledge (Kaytaz and Gul, 2014), this idea is reinforced by Lins Ferreira et al. (2017) when mentioning that there is very little marketing literature related to the impact of an economic crisis on purchase intentions, mainly in the analysis of changes in consumer behavior after the hecatomb. Even so, it is possible to affirm that during crises noticeable changes occur in the consumer (Smeral, 2009) because they dramatically affect the quality of life of a society through the increase in the unemployment rate, job insecurity, evaporation of wealth, cuts in investment, uncertainty and pessimism about the future (Stylidis and Terzidou, 2014).

That said, it is logical to think that an economic crisis also affects consumers psychologically, whether they lose their jobs or not, the possibility of losing their economic livelihood puts them under constant stress. (Kaytaz and Gul, 2014), which in many occasions results in a reduction in the consumption of products, especially those that are considered not very relevant. It should be mentioned that the relevance of a given product is subjective, since it will depend on the judgment of each buyer (Dutt and Padmanabhan, 2011).

\section{From baby boomer to generation $Z$ How could a pandemic affect the purchasing decisions of such diverse generations?}

In the sociological aspect, a generation is a group of individuals who share customs and beliefs, because they are approximately similar in age and have lived through very specific circumstances (Urbain et al., cited by Venter, 2017). Baby boomers, generation X (Xers), generation Y (Millennials) or generation Z (Zers); are very present terms within consumer behavior, since each of these presents characteristics that interact directly or indirectly in the purchase decision, hence their relevance.

First, there are the baby boomers; these were born between the years 1946 and 1964 (Gardiner et al., 2015; Sudbury-Riley, 2016) or 1946 and 1960 (Gurau, cited in Lissitsa and Kol, 2016); they like face-to-face social contact and some find it a bit difficult to adapt to the digital realm (Venter, 2017), seek to feel and look good (Kumar and Lin, cited by Rahulan et al., 2015), are independent (Siren and Haustein, 2015) traditional (Davis et al., 2006), positive, brand loyal (Beauchamp and Barnes, 2015) and have considerable financial capability following the independence of their children (Rahman and $\mathrm{Yu}, 2018$ ). They are said to have enjoyed job stability and prosperous times (Patterson et al., 2017), presumably healthier than their predecessors (Badley et al., 2015).

When contrasting the aforementioned characteristics with what was said in the previous subtopic, conflicts that could cause alterations in the purchase decision of this generation are denoted. Face-to-face social contact has been restricted and the digital sphere is enhanced as a result of covid-19, there is a tendency to prioritize health over any other aspect and there is complete uncertainty about the future. Paradoxically, baby boomers have received considerable attention from researchers in the tourism sector (Gardiner et al., 2015), which will most likely be the hardest hit by the pandemic. 
Secondly, there is generation X; whose members were born between 1965 and 1983 (Krishen et al., 2016) or 1961 and 1979 (Gurau, cited by Lissitsa and Kol, 2016); interestingly they are often considered the "ignored" generation (Taylor and Gao cited by Ivanova et al., 2018). It is possible to extrapolate such a statement in the context of the present review, since there is not much consumer behavior research on them (Gardiner et al., 2015).

Having endured two recessions in their lifetime (Eastman and Liu, cited by Krishen et al., 2016) they are arguably no strangers to crisis situations. Still, these have wreaked havoc on their development. In the research by Lager (2008) referred to by Ivanova et al. (2018) this idea is supported by mentioning that, although many of them have achieved higher education they have not come to fulfill their expectations due to such circumstances. After all of the above, it is possible to infer that many of them do not know real job, family or financial security (Davis et al., 2006).

Regarding their consumer behavior, it is said that they tend to have very little attachment towards brands and also tend not to be too interested in seeking recommendations from their peers ( $\mathrm{Yu}$ and Timmerman, cited by Chuang, 2018), so they are assumed to be materialistic (Williams et al., cited by Bulut et al., 2017) and individualistic (Gursoy et al., cited by Lissitsa and Kol, 2016). Consequently, the post-pandemic purchase decision of this generation is likely to be generally endowed with their practicality and convenience.

Thirdly, there is Generation Y, these were born between 1979 and 1994 (Smola and Sutton, cited by Myers and Sadaghiani, 2010). They are generally categorized as: reckless (Lissitsa and Kol, 2016), social status seekers (De Kerviler and Rodriguez, 2019), digital natives (Venter, 2017), self-centered (Myers and Sadaghiani, 2010), fashion obsessed (Williams and Page, cited by Valaei and Nikhashemi, 2017), predisposed to be influenced by celebrities (McCormick, 2016), sociable, unpredictable and even less brand loyal than their predecessors (Chuah et al. , 2017). Although interestingly they are also said to perceive brands as an extension of themselves (Novak et al., cited by McCormick, 2016).

Millennials' purchase decision seems to be more influenced by word of mouth than mass media (Sitel, cited by Muralidharan and Xue, 2016), of course, this also expands into their electronic counterpart. Liu et al. (2018) demonstrate this by detailing how millennials, especially those with low self-esteem, have a desire to travel by observing a significant other share their tourism experiences via social media.

It is said that this generation is open to change and in favor of digital solutions (Hwang and Griffiths, 2017), so it would not be unreasonable to think that the empowerment of the digital sphere will not be something difficult for them to assimilate. However, as far as the psychological part is concerned, there could be conflicts at the time of purchase, particularly because of the very marked hedonism in this generation (Williams et al., cited by Bulut et al., 2017).

Finally, mention is made of Generation Z, composed of young adults born since 1995 (Fister-Gale, cited by Priporas et al., 2017). Priporas et al. (2019) citing Euromonitor (2018), Bernstein (2015) and Yussof (2018) tell us that members of this generation are characterized by being pragmatic, socially responsible and individualistic; they stand out for having been born in a completely digital world and in their excessive use of social networks, which inevitably shape their life.

The first three generations mentioned are the most relevant for marketing, since they currently represent a huge percentage of adult consumers (Wuest et al., cited by Gardiner et al., 2015), However, starting to fully investigate the consumer behavior of generation $Z$ would be prudent and even necessary, since experts such as Priporas et al. (2017) referring to Schlossberg (2016) comment that generation $Z$ seems to behave very differently from their predecessors, which according to them could cause changes in consumer behavior.

It is very likely that some of the characteristics presented in a general way vary in certain nations, this is something that has already been contemplated and openly discussed (Leask et al., cited by Rita et al., 2018). Still, they serve as a general framework or point of comparison for delimited research in a specific area.

\section{Security: The return of a factor displaced by superficiality?}

Maslow's (1943) widely known and strongly discussed hierarchy of needs or pyramid presents very strict dependencies between the different groups of needs of this theory. That is to say, the fulfillment of the needs of 
the first block (physiological) causes the next set of needs (security) to emerge. Similarly, the satisfaction of the latter will allow access to the third block (affiliation), and this constant is repeated with the recognition block until reaching self-actualization.

Tay and Diener (2011) have empirically demonstrated that this order does not necessarily occur due to various external factors. An example of these can be seen in the research of Tang and Safwat (1998), where it is noted that there is a notorious difference in the importance of the needs of a population when their country is at war and in peace, it can be stated that these results reject Maslow's universal theory, since in the war scenario security is more relevant.

When there are changes in the prioritization of needs, there will inevitably be variations in the purchase decision, which of course will revolve around the agent that causes this change. It can be inferred that, in a crisis situation such as the pandemic of the new coronavirus, most human beings stop opting for conspicuous consumption raised by Thorstein Veblen in 1899, which is defined as the purchase of excessively expensive goods for the sole purpose of demonstrating or maintaining a high social status (Veblen, cited by Eckhardt et al., 2014). Specifically, it is likely that during the pandemic the recognition quadrant will often take a back seat to security.

\section{CONCLUSIONS}

In short, the purchase decision is a multidisciplinary concept that contemplates internal factors of human beings and factors completely external to them. Due to its complexity, schemes that allow an easy understanding of the possible factors that may influence at the time of purchase, either in person or digitally, are embodied. In order to deepen the understanding of this concept, empirical research in specific contexts is recommended.

The pandemic of the new coronavirus is likely to cause a wide range of changes in consumer behavior due to the psychological and economic impact it has had on consumers. Although its incidence on purchasing decisions needs to be studied in more detail and depth through multivariate research, there are already precedents that demonstrate how a similar smaller-scale disaster caused changes in consumer preferences.

It can be intuited that the changes that will occur in consumers as a result of covid-19 will not be uniform. Generational theory provides a general framework of the characteristics of each generation, and by contrasting these with the effects of the pandemic, certain critical points can be denoted, which will likely cause changes in their purchasing behavior. It is highly advisable to conduct empirical research in specific locations, since there are very specific generational characteristics specific to each area.

Maslow's theory has been refuted by several academics, since it does not take into account the environment or people's circumstances when defining the hierarchy of their needs. Empirically, it has been proven that individuals tend to prioritize security in crisis situations, so it is expected that, in the face of the coronavirus pandemic, the purchase decision of most people will focus on their security and give less relevance to recognition. In spite of this, it should be noted that this theory provides a comprehensive idea of consumer needs, which may facilitate the approach of future research.

Currently, it can be said that the purchase decision in a pandemic context is very poorly developed, as evidenced by the lack of a scientific consensus regarding its influencing and determining factors. In conclusion, the consumer purchase decision may be more methodical and slightly more rational. This would be so, due to the enormous implication of digital media, as a platform to search for information or purchase products, and the experience of having lived through a crisis situation surrounded by economic and psychological uncertainty. It should be emphasized that the changes will be subject to demographic, psychographic, behavioral and even geographical factors. For this reason, it is necessary to conduct empirical research that will provide truly conclusiveresults. 


\section{REFERENCES}

1. Achar, C., So, J., Agrawal, N. y Duhachek, A. (2016). What we feel and why we buy: the influence of emotions on consumer decision-making, Current Opinion in Psychology, 10, 166-170. https://doi.org/10.1016/j.copsyc.2016.01.009

2. Arafat, S.M.Y., Kar, S.K., Marthoenis, M., Sharma, P., Hoque Apu, E. and Kabir, R. (2020). Psychological underpinning of panic buying during pandemic (COVID-19). Psychiatry Research, 289, 113061. https://doi.org/10.1016/j.psychres.2020.113061

3. Badgaiyan, A.J. and Verma, A. (2015). Does urge to buy impulsively differ from impulsive buying behaviour? Assessing the impact of situational factors. Journal of Retailing and Consumer Services, 22, 145-157. https://doi.org/10.1016/j.jretconser.2014.10.002

4. Badley, E.M., Canizares, M., Perruccio, A.V., Hogg-Johnson, S. and Gignac, M.A.M. (2015). Benefits gained, benefits lost: comparing baby boomers to other generations in a longitudinal cohort study of selfrated health. Milbank Quarterly, 93 (1), 40-72. https://doi.org/10.1111/1468-0009.12105

5. Batra, R. and Keller, K.L. (2016). Integrating marketing communications: new findings, new lessons, and new ideas. Journal of Marketing, 80 (6), 122-145. https://doi.org/10.1509/jm.15.0419

6. Beauchamp, M.B. and Barnes, D.C. (2015). Delighting Baby Boomers and Millennials: Factors that Matter Most. Journal of Marketing Theory and Practice, 23 (3), 338-350. https://doi.org/10.1080/10696679.2015.1032472

7. Bellini, S., Cardinali, M.G. and Grandi, B. (2017). A structural equation model of impulse buying behaviour in grocery retailing. Journal of Retailing and Consumer Services, 36, 164-171. https://doi.org/10.1016/j.jretconser.2017.02.001

8. Bulut, Z.A., Kökalan Çımrin, F. and Doğan, O. (2017). Gender, generation and sustainable consumption: Exploring the behaviour of consumers from Izmir, Turkey. International Journal of Consumer Studies, 41 (6), 597-604. https://doi.org/10.1111/ijcs.12371

9. Calhoon, G. and Tye, K. (2015). Resolving the neural circuits of anxiety. Nature Neuroscience, 18 (10), 1394-1404. https://doi.org/10.1038/nn.4101

10. Chetty, R. (2015). Behavioral Economics and Public Policy: A Pragmatic Perspective. American Economic Review, 105 (5), 1-33. https://doi.org/10.1257/aer.p20151108

11. Chuah, S.H.W., Marimuthu, M., Kandampully, J. and Bilgihan, A. (2017). What drives Gen Y loyalty? Understanding the mediated moderating roles of switching costs and alternative attractiveness in the value-satisfaction-loyalty chain. Journal of Retailing and Consumer Services, 36, 124-136. https://doi.org/10.1016/j.jretconser.2017.01.010

12. Chuang, S. (2018). Generation Xers' performance and development in midlife transition. Human Resource Development International, 22 (1), 101-112. https://doi.org/10.1080/13678868.2018.1440130

13. Cohen, M., and Tavares, J. (2020). Who are the Most At-Risk Older Adults in the COVID-19 Era? It's Not Just Those in Nursing Homes. Journal of Aging \& Social Policy, 32 (4/5), 380-386. https://doi.org/10.1080/08959420.2020.1764310

14. Cosenza, T.R., Solomon, M.R. and Kwon, W. (2014). Credibility in the blogosphere: A study of measurement and influence of wine blogs as an information source. Journal of Consumer Behaviour, 14 (2), 71-91. https://doi.org/10.1002/cb.1496

15. Court, D., Elzinga, D., Mulder, S. and Vetvik, O. (2009). The Consumer Decision Journey. McKinsey Quarterly. Recuperado el 14 de Julio de 2020, de https://maxket.com/wpcontent/uploads/2014/08/theconsumerdecisionjourney-110105124644-phpapp02.pdf.

16. Cryan, J.F. and Holmes, A. (2005). The ascent of mouse: advances in modelling human depression and anxiety. Nature Reviews Drug Discovery, 4 (9), 775-790. https://doi.org/10.1038/nrd1825

17. Davis, J.B., Pawlowski, S.D. and Houston, A. (2006). Work Commitments of Baby Boomers and GenXers in the it Profession: Generational Differences or Myth? Journal of Computer Information Systems, 46 (3), 43-49.

18. De Kerviler, G. and Rodriguez, C.M. (2019). Luxury brand experiences and relationship quality for Millennials: The role of self-expansion. Journal of Business Research, 102, 250-262 https://doi.org/10.1016/j.jbusres.2019.01.046

19. Depoux, A., Martin, S., Karafillakis, E., Preet, R., Wilder-Smith, A. and Larson, H. (2020). The pandemic 
of social media panic travels faster than the COVID-19 outbreak. Journal of Travel Medicine, 27 (3), 12. https://doi.org/10.1093/jtm/taaa031

20. Dutt, P. and Padmanabhan, V. (2011). Crisis and Consumption Smoothing. Marketing Science, 30 (3), 491-512. https://doi.org/10.1287/mksc.1100.0630

21. Eckhardt, G.M., Belk, R.W. and Wilson, J.A.J. (2014). The rise of inconspicuous consumption. Journal of Marketing Management, 31 (7-8), 807-826. https://doi.org/10.1080/0267257x.2014.989890

22. Erku, D.A., Belachew, S.A., Abrha, S., Sinnollareddy, M., Thomas, J., Steadman, K.J. and Tesfaye, W. (2020). When fear and misinformation go viral: Pharmacists' role in deterring medication misinformation during the "infodemic" surrounding COVID-19. Research in Social and Administrative Pharmacy. https://doi.org/10.1016/j.sapharm.2020.04.032

23. Ewerhard, A.C., Sisovsky, K. and Johansson, U. (2019). Consumer decision-making of slow moving consumer goods in the age of multi-channels. The International Review of Retail, Distribution and Consumer Research, 29(1) , 1-22. https://doi.org/10.1080/09593969.2018.1537191

24. Fawcett, T.W., Fallenstein, B., Higginson, A.D., Houston, A.I., Mallpress, D.E.W, Trimmer, P.C. and McNamara, J.M. (2014). The evolution of decision rules in complex environments. Trends in Cognitive Sciences, 18 (3), 153-161. https://doi.org/10.1016/j.tics.2013.12.012

25. Flowers, P., Davis, M., Lohm, D., Waller, E. and Stephenson, N. (2014). Understanding pandemic influenza behaviour: An exploratory biopsychosocial study. Journal of Health Psychology, 21 (5), 759769. https://doi.org/10.1177/1359105314537542

26. Foxall, G.R. (2003). The behavior analysis of consumer choice: An introduction to the special issue. Journal of Economic Psychology, 24 (5), 581-588. https://doi.org/10.1016/s0167-4870(03)00002-3

27. Frank, B. and Schvaneveldt, S. (2016). Understanding consumer reactions to product contamination risks after national disasters: The roles of knowledge, experience, and information sources. Journal of Retailing and Consumer Services, 28, 199-208. https://doi.org/10.1016/j.jretconser.2015.08.005

28. Frederiks, E.R., Stenner, K. and Hobman, E.V. (2015). Household energy use: Applying behavioural economics to understand consumer decision-making and behaviour. Renewable and Sustainable Energy Reviews, 41, 1385-1394. https://doi.org/10.1016/j.rser.2014.09.026

29. Gardiner, S., Grace, D. and King, C. (2015). Is the Australian domestic holiday a thing of the past? Understanding baby boomer, Generation $X$ and Generation $Y$ perceptions and attitude to domestic and international holidays. Journal of Vacation Marketing, 21 (4), 336-350. https://doi.org/10.1177/1356766715580188

30. Gobat, N., Gal, M., Butler, C., Webb, S., Francis, N., Stanton, H., ... Nichol, A. (2017). Talking to the people that really matter about their participation in pandemic clinical research: A qualitative study in four European countries. Health Expectations, 21 (1), 387-395. https://doi.org/10.1111/hex.12634

31. Godinho, S., Prada, M. and Garrido, M.V. (2016). Under Pressure: An Integrative Perspective of Time Pressure Impact on Consumer Decision-Making. Journal of International Consumer Marketing, 28 (4), 251-273. https://doi.org/10.1080/08961530.2016.1148654

32. Hinterhuber, A. (2015). Violations of rational choice principles in pricing decisions. Industrial Marketing Management, 47, 65-74. https://doi.org/10.1016/j.indmarman.2015.02.006

33. Holt-Lunstad, J., Smith, T.B., Baker, M., Harris, T. and Stephenson, D. (2015). Loneliness and Social Isolation as Risk Factors for Mortality. Perspectives on Psychological Science, 10 (2), 227237. https://doi.org/10.1177/1745691614568352

34. House, J. (2001). Social isolation kills, but how and why? Psychosomatic Medicine, 63 (2), 273-274. https://doi.org/10.1097/00006842-200103000-00011

35. Huete-Alcocer, N. (2017). A Literature Review of Word of Mouth and Electronic Word of Mouth: Implications for Consumer Behavior. Frontiers in Psychology, 8. https://doi.org/10.3389/fpsyg.2017.01256

36. Hwang, J. and Griffiths, M. A. (2017). Share more, drive less: Millennials value perception and behavioral intent in using collaborative consumption services. Journal of Consumer Marketing, 34 (2), 132-146. https://doi.org/10.1108/jcm-10-2015-1560

37. Ivanova, O., Flores-Zamora, J., Khelladi, I. and Ivanaj, S. (2018). The generational cohort effect in the context of responsible consumption. Management Decision, 57 (5), 1162-1183 https://doi.org/10.1108/md-12-2016-0915 
38. Karimi, S., Holland, C.P. and Papamichail, K.N. (2018). The impact of consumer archetypes on online purchase decision-making processes and outcomes: A behavioural process perspective. Journal of Business Research, 91, 71-82. https://doi.org/10.1016/j.jbusres.2018.05.038

39. Karimi, S., Papamichail, K. and Holland, C.P. (2015). The effect of prior knowledge and decision-making style on the online purchase decision-making process: A typology of consumer shopping behaviour. Decision Support Systems, 77, 137-147. https://doi.org/10.1016/j.dss.2015.06.004

40. Kaytaz, M. and Gul, M.C. (2014). Consumer response to economic crisis and lessons for marketers: The Turkish experience. Journal of Business Research, 67 (1), 27012706. https://doi.org/10.1016/j.jbusres.2013.03.019

41. Kelly, J.R., Iannone, N.E. and McCarty, M.K. (2015). Emotional contagion of anger is automatic: An evolutionary explanation. British Journal of Social Psychology, 55 (1), 182-191. https://doi.org/10.1111/bjso.12134

42. Kemp, E., Kennett-Hensel, P.A. and Williams, K. (2014). The Calm before the Storm: Examining Emotion Regulation Consumption in the Face of an Impending Disaster. Psychology \& Marketing, 31 (11), 933945. https://doi.org/10.1002/mar.20744

43. Krishen, A.S., Berezan, O., Agarwal, S. and Kachroo, P. (2016). The generation of virtual needs: Recipes for satisfaction in social media networking. Journal of Business Research, 69 (11), 5248-5254. https://doi.org/10.1016/j.jbusres.2016.04.120

44. Laing, T. (2020). The economic impact of the Coronavirus 2019 (Covid2019): Implications for the mining industry, Extractive Industries and Society, 7 (2), 580-582. https://doi.org/10.1016/j.exis.2020.04.003

45. Larson, H. (2018). The biggest pandemic risk? Viral misinformation. Nature, 562 (7727), 309. https://doi.org/10.1038/d41586-018-07034-4

46. Lins Ferreira, V., Pereira da Veiga, C. R., Kudlawicz-Franco, C., Scalercio, P., Ramires, Pontarolo, R., ... da Veiga, C. P. (2017). Generic drugs in times of economic crisis: Are there changes in consumer purchase intention? Journal of Retailing and Consumer Services, 37, 1-7. https://doi.org/10.1016/j.jretconser.2017.02.008

47. Lissitsa, S. and Kol, O. (2016). Generation Xvs. Generation Y-A decade of online shopping. Journal of Retailing and Consumer Services, 31, 304-312. https://doi.org/10.1016/j.jretconser.2016.04.015

48. Liu, H., Wu, L. and Li, X. (2018). Social Media Envy: How Experience Sharing on Social Networking Sites Drives Millennials' Aspirational Tourism Consumption. Journal of Travel Research, 58 (3). https://doi.org/10.1177/0047287518761615

49. Lunn, P.D. (2015). Are Consumer Decision-Making Phenomena a Fourth Market Failure? Journal of Consumer Policy, 38, 315-330._https://doi.org/10.1007/s10603-014-9281-1

50. Maslow, A.H. (1943). A theory of human motivation. Psychological Review, 50 (4), 370-396. https://doi.org/10.1037/h0054346

51. McCormick, K. (2016). Celebrity endorsements: Influence of a product-endorser match on Millennials attitudes and purchase intentions. Journal of Retailing and Consumer Services, 32, 39-45. https://doi.org/10.1016/j.jretconser.2016.05.012

52. Mian, A. and Khan, S. (2020). Coronavirus: the spread of misinformation. BMC Medicine, 18 (89). https://doi.org/10.1186/s12916-020-01556-3

53. Mitchell, V. (1999). Consumer perceived risk: conceptualisations and models. European Journal of Marketing, 33 (1/2), 163-195. https://doi.org/10.1108/03090569910249229

54. Muralidharan, S. and Xue, F. (2016). Personal networks as a precursor to a green future: a study of "green" consumer socialization among young millennials from India and China. Young Consumers, 17 (3), 226-242. https://doi.org/10.1108/yc-03-2016-00586

55. Myers, K.K. and Sadaghiani, K. (2010). Millennials in the Workplace: A Communication Perspective on Millennials' Organizational Relationships and Performance. Journal of Business and Psychology, 25, 225-238. https://doi.org/10.1007/s10869-010-9172-7

56. Nicola, M., Alsafi, Z., Sohrabi, C., Kerwan, A., Al-Jabir, A., Iosifidis, C., ... Agha R. (2020). The SocioEconomic Implications of the Coronavirus and COVID-19 Pandemic: A Review. International Journal of Surgery, 78, 185-193. https://doi.org/10.1016/j.ijsu.2020.04.018

57. Pantano, E., Rese, A. and Baier, D. (2017). Enhancing the online decision-making process by using augmented reality: A two country comparison of youth markets. Journal of Retailing and Consumer 
Services, 38, 81-95. https://doi.org/10.1016/j.jretconser.2017.05.011

58. Pappas, N. (2016). Marketing strategies, perceived risks, and consumer trust in online buying behaviour. Journal of Retailing and Consumer Services, 29, 92-103. https://doi.org/10.1016/j.jretconser.2015.11.007

59. Patterson, I., Sie, L., Balderas-Cejudo, A. and Rivera-Hernaez, O. (2017). Changing Trends in the Baby Boomer Travel Market: Importance of Memorable Experiences. Journal of Hospitality Marketing \& Management, 26 (4), 347-360. https://doi.org/10.1080/19368623.2017.1255162

60. Priporas, C., Stylos, N. and Fotiadis, A. (2017). Generation Z consumers' expectations of interactions in smart retailing: A future agenda. Computers in Human Behavior, 77, 374-381. https://doi.org/10.1016/j.chb.2017.01.058

61. Priporas, C., Stylos, N. and Kamenidou, I. (2019). City image, city brand personality and generation Z residents' life satisfaction under economic crisis: Predictors of city-related social media engagement. Journal of Business Research, 119. https://doi.org/10.1016/j.jbusres.2019.05.019

62. Prochazkova, E. and Kret, M. E. (2017). Connecting minds and sharing emotions through mimicry: A neurocognitive model of emotional contagion. Neuroscience \& Biobehavioral Reviews, 80, 99114. https://doi.org/10.1016/j.neubiorev.2017.05.013

63. Rabin, M. (2002). A perspective on psychology and economics. European Economic Review, 46 (4-5), 657-685. https://doi.org/10.1016/s0014-2921(01)00207-0

64. Rahman, O. and Yu, H. (2018). A study of Canadian female baby boomers: Physiological and psychological needs, clothing choice and shopping motives. Journal of Fashion Marketing and Management, 22 (4), 509-526. https://doi.org/10.1108/JFMM-09-2017-0100

65. Rahulan, M., Troynikov, O., Watson, C., Janta, M. and Senner, V. (2015). Consumer behavior of generational cohorts for compression sportswear. Journal of Fashion Marketing and Management: An International Journal, 19 (1), 87-104. https://doi.org/10.1108/jfmm-05-2013-0072

66. Rezaei, S. (2015). Segmenting consumer decision-making styles (CDMS) toward marketing practice: A partial least squares (PLS) path modeling approach. Journal of Retailing and Consumer Services, 22, 1 15. https://doi.org/10.1016/j.jretconser.2014.09.001

67. Rita, P., Brochado, A. and Dimova, L. (2018). Millennials' travel motivations and desired activities within destinations: A comparative study of the US and the UK. Current Issues in Tourism, 22 (16), 2034-2050. https://doi.org/10.1080/13683500.2018.1439902

68. Rodiger, M. and Hamm, U. (2015). How are organic food prices affecting consumer behaviour? A review. Food Quality and Preference, 43, 10-20. https://doi.org/10.1016/j.foodqual.2015.02.002

69. Roozmand, O., Ghasem-Aghaee, N., Hofstede, G., Nematbakhsh, M., Baraani, A. and Verwaart, T. (2011). Agent-based modeling of consumer decision making process based on power distance and personality. Knowledge-Based Systems, 24 (7), 1075-1095. https://doi.org/10.1016/j.knosys.2011.05.001

70. Rousseau, C., Moreau, N., Dumas, M., Bost, I., Lefebvre, S. and Atlani-Duault, L. (2013). Public media communications about H1N1, risk perceptions and immunization behaviours: A Quebec-France comparison. Public Understanding of $\quad$ Science, $24 \quad$ (2), 225240. https://doi.org/10.1177/0963662513495149

71. Schaafsma, S., Pfaff, D., Spunt, R. and Adolphs, R. (2015). Deconstructing and reconstructing theory of mind. Trends in Cognitive Sciences, 19 (2), 65-72. https://doi.org/10.1016/j.tics.2014.11.007

72. Shigemura, J., Ursano, R., Morganstein, J., Kurosawa, M. and Benedek, D. (2020). Public responses to the novel 2019 coronavirus (2019- $n \mathrm{CoV})$ in Japan: mental health consequences and target populations. Psychiatry and Clinical Neurosciences, 74 (4), 281-282. https://doi.org/10.1111/pcn.12988

73. Sim, K., Chua, H., Vieta, E. and Fernandez, G. (2020). The anatomy of panic buying related to the current $\begin{array}{lllll}\text { COVID-19 Pandemic. } & \text { Psychiatry }\end{array}$ https://doi.org/10.1016/j.psychres.2020.113015

74. Simon, H. (1986). Rationality in Psychology and Economics. The Journal of Business, 59 (4), $209-224$. https://doi.org/10.1086/296363

75. Siren, A. and Haustein, S. (2015). How do baby boomers' mobility patterns change with retirement? Ageing and Society, 36 (5), 988-1007. https://doi.org/10.1017/s0144686x15000100

76. Smeral, E. (2009). The Impact of the Financial and Economic Crisis on European Tourism. Journal of Travel Research, 48 (1), 3-13. https://doi.org/10.1177/0047287509336332 
77. Smith, G., Ng, F. and Ho, W. (2020). COVID-19: Emerging compassion, courage and resilience in the face of misinformation and adversity. Journal of Clinical Nursing, 29 (9-10), 1425-1428. https://doi.org/10.1111/jocn.15231

78. Sneath, J., Lacey, R. and Kennett-Hensel, P. (2008). Coping with a natural disaster: Losses, emotions, and impulsive and compulsive buying. Marketing Letters, 20 (1),45-60. https://doi.org/10.1007/s11002008-9049-y

79. Snoek, F.J., Bremmer, M.A. and Hermanns, N. (2015). Constructs of depression and distress in diabetes: time for an appraisal. The Lancet Diabetes \& Endocrinology, 3 (6), 450-460. https://doi.org/10.1016/s2213-8587(15)00135-7

80. Sterman, J. and Dogan, G. (2015). "I'm not hoarding, I'm just stocking up before the hoarders get here”. Journal of Operations Management, 39-40 (1), 6-22. https://doi.org/10.1016/j.jom.2015.07.002

81. Stylidis, D. and Terzidou, M. (2014). Tourism and the economic crisis in Kavala, Greece. Annals of Tourism Research, 44, 210-226. https://doi.org/10.1016/j.annals.2013.10.004

82. Sudbury-Riley, L. (2016). The baby boomer market maven in the United Kingdom: an experienced diffuser of marketplace information. Journal of Marketing Management, 32 (7-8), 716749. https://doi.org/10.1080/0267257x.2015.1129985

83. Sunaga, T., Park, J. and Spence, C. (2016). Effects of Lightness-Location Congruency on Consumers' Purchase Decision-Making. Psychology \& Marketing, 33 (11), 934-950. https://doi.org/10.1002/mar.20929

84. Tang, T. and Safwat A. (1998). Importance of Human Needs During Retrospective Peacetime and the Persian Gulf War: Mideastern Employees. International Journal of Stress Management, 5 (1), $25-37$. https://doi.org/10.1023/a:1022902803386

85. Tay, L. and Diener, E. (2011). Needs and subjective well-being around the world. Journal of Personality and Social Psychology, 101 (2), 354-365. https://doi.org/10.1037/a0023779

86. Taylor, J. W. (1974). The Role of Risk in Consumer Behavior. Journal of Marketing, 38 (2), 5460. https://doi.org/10.1177/002224297403800211

87. Thomé, A., Scavarda, L. and Scavarda, A. (2016). Conducting systematic literature review in operations $\begin{array}{llllll}\text { management. Production Planning } \quad \& \quad \text { Control, } 27 & \text { (5), } 408-420 .\end{array}$ https://doi.org/10.1080/09537287.2015.1129464

88. Torales, J., O'Higgins, M., Castaldelli-Maia, J. and Ventriglio, A. (2020). The outbreak of COVID-19 coronavirus and its impact on global mental health. International Journal of Social Psychiatry. Advance online publication. https://doi.org/10.1177/0020764020915212

89. Valaei, N. and Nikhashemi, S. (2017). Generation Y consumers' buying behaviour in fashion apparel industry: a moderation analysis. Journal of Fashion Marketing and Management, 21 (4), 523-543. https://doi.org/10.1108/jfmm-01-2017-0002

90. Venter, E. (2017). Bridging the communication gap between Generation $Y$ and the Baby Boomer generation. International Journal of Adolescence and Youth, 22 (4), 497-507. https://doi.org/10.1080/02673843.2016.1267022

91. Viio, P. and Gronroos, C. (2016). How buyer-seller relationship orientation affects adaptation of sales processes to the buying process. Industrial Marketing Management, 52, 37-46. https://doi.org/10.1016/j.indmarman.2015.07.013

92. Voramontri, D. and Klieb, L. (2019). Impact of social media on consumer behaviour. International. Journal of Information and Decision Sciences, 11 (3), 209-233. https://doi.org/10.1504/ijids.2019.101994

93. Wang, Y. and Yu, C. (2017). Social interaction-based consumer decision-making model in social commerce: The role of word of mouth and observational learning. International Journal of Information Management, 37 (3), 179-189. https://doi.org/10.1016/j.ijinfomgt.2015.11.005

94. Wen, Z., Huimin, G. and Kavanaugh, R. (2005). The Impacts of SARS on the Consumer Behaviour of Chinese Domestic Tourists. Current Issues in Tourism, 8 (1), 2238. https://doi.org/10.1080/13683500508668203

95. Wilder-Smith, A. and Freedman, D. (2020). Isolation, quarantine, social distancing and community containment: pivotal role for old-style public health measures in the novel coronavirus (2019-nCoV) outbreak. Journal of Travel Medicine, 27 (2), 1-4. https://doi.org/10.1093/jtm/taaa020 
96. Wilson, M. and Chen, L. (2020). Travelers Give Wings to Novel Coronavirus (2019- nCoV). Journal of Travel Medicine, 27 (2), 1-3. https://doi.org/10.1093/jtm/taaa015

97. Wu, P. and Lee, C. (2015). Impulse buying behaviour in cosmetics marketing activities. Total Quality $\begin{array}{llllll}\text { Management \& } & \text { Business } & \text { Excellence, } & 27 & \text { (9-10), } & 1091-111 .\end{array}$ https://doi.org/10.1080/14783363.2015.1060851

98. Xiang, Y., Yang, Y., Li, W., Zhang, L., Zhang, Q., Cheung, T. and Ng, C. (2020). Timely mental health care for the 2019 novel coronavirus outbreak is urgently needed. The Lancet Psychiatry, 7 (3), 228-229. https://doi.org/10.1016/s2215-0366(20)30046-8

99. Yuen, K., Wang, X., Ma, F. and Li, K. (2020). The Psychological Causes of Panic Buying Following a Health Crisis. International Journal of Environmental Research and Public Health, 17 (10), 3513. https://doi.org/10.3390/ijerph17103513 